\title{
KOMPOSISI DAN FLUKTUASI HASIL TANGKAPAN IKAN CUCUT DOMINAN YANG TERTANGKAP RAWAI TUNA PERMUKAAN
}

\author{
Dharmadi1), Suprapto²), dan Agustinus Anung Widodo"1) \\ 1) Peneliti pada Pusat Riset Perikanan Tangkap, Ancol-Jakarta \\ 2) Peneliti pada Balai Riset Perikanan Laut, Muara Baru-Jakarta \\ Teregristrasi I tanggal: 12 Maret 2008; Diterima setelah perbaikan tanggal: 2 Juni 2008; \\ Disetujui terbit tanggal: 13 Oktober 2008
}

\begin{abstract}
ABSTRAK
Perikanan rawai tuna memiliki kontribusi cukup besar terhadap hasil tangkapan ikan cucut (Requiem shark sp.) di perairan Samudera Hindia. Hasil tangkapan rawai tuna sebagian besar didaratkan di 2 pendaratan ikan utama yaitu Pelabuhan Perikanan Pelabuhan Ratu dan Pelabuhan Perikanan Samudera Cilacap. Kegiatan penelitian untuk mengetahui komposisi dan fluktuasi hasil tangkapan ikan cucut (Requiem shark sp.) dominan pada rawai tuna permukaan berbasis di 2 lokasi pendaratan ikan tersebut dilakukan pada tahun 2004. Hasil penelitian menunjukkan bahwa komposisi hasil tangkapan cucut (Requiem shark sp.) pada rawai tuna permukaan didominansi oleh jenis ikan cucut karet atau selendang (Prionace glauca) antara 40 sampai dengan 90\%, sedangkan komposisi jenis ikan cucut lain seperti ikan cucut lanjaman (Carcharhinus falciformis dan Carcharhinus sorrah), cucut paitan (Alopias superciliosus), cucut tikusan (Alopias pelagicus), dan cucut mako (Isurus sp.) antara 3 sampai dengan 30\%. Hasil tangkapan ikan cucut (Requiem shark sp.) terhadap hasil tangkapan total rawai tuna permukaan antara 5 sampai dengan 25\% pada tahun 2004 dari rata-rata 85 unit kapal rawai tuna yang beroperasi di perairan Samudera Hindia. Hasil tangkapan ikan cucut (Requiem shark sp.) tertinggi terjadi pada bulan Juli sampai dengan Agustus. Hasil tangkapan ini berkaitan dengan kondisi cuaca (Requiem shark sp.) pada saat nelayan melakukan penangkapan ikan di laut.
\end{abstract}

\section{KATAKUNCI: $\quad$ komposisi, ikan cucut, rawai tuna, Samudera Hindia}

ABSTRACT: Catch composition and fluctuation of shark caught by surface long line fishery that operated in the Indian Ocean. By: Dharmadi, Suprapto, and Agustinus Anung Widodo

\begin{abstract}
Tuna long lines fisheries have more contributed on the catch of shark (Requiem shark sp.) in the Indian Ocean. Most of catch from tuna long lines landed at two main landing sites of tuna long line which operated in the Indian Ocean were Pelabuhan Ratu and Cilacap. This study was conducted at that two landing sites during 2004. The result showed that shark (Requiem shark sp.) catch composition on tuna long line was dominated by blue shark, Prionace glauca (40 to 90\%), while other sharks i.e. silky shark (Carcharhinus falciformis), spot tail shark (Carcharhinus sorrah), big eye thresher (Alopias superciliosus), pelagic thresher (Alopias pelagicus), and mako shark (Isurus sp.) between 3 to $30 \%$ from the total catch of shark (Requiem shark sp.). Percentage catch of sharks (Requiem shark sp.) againts total catch of tuna surface long line during 2004 was ranging 5 to $25 \%$ from everage of 85 unit of tuna long line boat that operated in the Indian Ocean. Catch fluctuation related with the weather conditon when the fishers are fishing activity at sea. The high catch of shark (Requiem shark sp.) was occur on July until August.
\end{abstract}

\section{KEYWORDS: composition, shark, surface long lines, Indian Ocean}

\section{PENDAHULUAN}

Perkembangan pemanfaatan sumber daya ikan cucut (Requiem shark sp.) dan pari (Plesiobatis sp.) di Indonesia adalah sejalan dengan perkembangan perikanan rawai tuna Indonesia. Secara komersial, rawai tuna di Indonesia dikembangkan sejak awal tahun 1970-an. Ikan cucut (Requiem shark sp.) dan pari (Plesiobatis sp.) merupakan hasil tangkapan sampingan terbesar pada perikanan rawai tuna. Pada awalnya, ikan cucut (Requiem shark sp.) yang tertangkap rawai tuna hanya dimanfaatkan sirip, sedangkan ikan pari (Plesiobatis sp.) dibuang kembali ke laut dalam keadaan hidup atau mati. Sejak tahun 1988, ketika harga sirip ikan cucut (Requiem shark sp.) mulai meningkat, banyak nelayan yang mengkhususkan menangkap komoditas tersebut. Nelayan Tanjung Luar (Nusa Tenggara Barat) dan Pelabuhan Ratu (Jawa Barat) mengembangkan rawai hanyut khusus untuk menangkap ikan cucut (Requiem shark sp.). Nelayan Sumatera Barat, Bengkulu, Labuan (Banten), dan Cilacap berhasil mengembangkan rawai dasar khusus untuk menangkap ikan cucut botol (Squalidae) untuk diambil 
minyaknya. Informasi yang menarik bahwa armada rawai tuna mengoperasikan alat di daerah penangkapan ikan cucut (Requiem shark sp.) (dekat perairan karang) terlebih dahulu sebelum ke daerah penangkapan tuna (Anung \& Widodo, 2002). Hal ini, dimaksudkan untuk mendapatkan hasil tangkapan ikan cucut (Requiem shark sp.) yang juga mempunyai nilai ekonomis tinggi.

Sumber daya ikan cucut (Requiem shark sp.) termasuk kelompok Elasmobranchii dengan sifat biologis antara lain siklus hidup yang panjang, pertumbuhan dan kematangan kelamin lambat serta fekunditas yang rendah (Compagno, 1984; Last \& Stevens, 1994; Castro et al., 1999). Sebagai ilustrasi, pada salah satu jenis ikan cucut (Requiem shark sp.) dari marga Alopias (Alopidae), induk betina dewasa hanya menghasilkan 2 sampai dengan 4 ekor dalam 1 kali siklus reproduksi. Sedangkan untuk mencapai kematangan kelamin, jenis ini memerlukan waktu antara 9 sampai dengan 10 tahun untuk jantan, dan 12 sampai dengan 13 tahun untuk cucut betina (Liu et al. vide Castro et al., 1999). Karakter tersebut mengakibatkan mudah mengalami penurunan stok dengan cepat akibat tekanan penangkapan yang intensif. Akibat serius yang akan muncul terjadi kepunahan sumber daya ikan cucut (Requiem shark sp.) dan pari (Plesiobatis sp.) jika intensitas tekanan melalui penangkapan terus meningkat.

Indonesia telah diakui oleh dunia internasional sebagai negara dengan jumlah tangkapan ikan cucut (Requiem sharksp.) per tahun yang terbesar di dunia (Stevens et al., 2000; Bonfil, 2002). Dalam rangka mempertahankan keberadaan sumber daya ikan cucut (Requiem shark sp.) dan pari (Plesiobatis sp.), lembaga konservasi seperti hal IUCN yang telah menyusun daftar merah (red list) perlindungan beberapa jenis ikan cucut (Requiem shark sp.) terutama jenis-jenis yang sering tertangkap nelayan dan diduga telah terancam kelestarian (IUCN, 2005). Sejauh ini data dan informasi yang akurat mengenai sumber daya ikan cucut (Requiem shark sp.) di Indonesia dilakukan perbaikan. Hal ini, karena tidak ada pencatatan data terutama dari beberapa lokasi pendaratan ikan yang tidak melakukan kegitan lelang. Di sisi lain, desakkan dunia untuk mendukung pelaksanaan konservasi beberapa sumber daya ikan cucut (Requiem shark sp.) sangat intensif. Beberapa penelitian awal telah dilaksanakan sebagai langkah untuk memperoleh data yang akurat dan dapat dipertanggungjawabkan (accountable) sebagai bahan penyusunan kebijakan pengelolaan sumber daya ikan cucut (Requiem shark sp.) di Indonesia.
Berkaitan hal tersebut, maka telah dilakukan studi komposisi dan fluktuasi tangkapan ikan cucut (Requiem shark sp.) pada perikanan pancing rawai tuna, yang sampai dengan saat ini ikan cucut (Requiem shark sp.) merupakan hasil tangkapan sampingan terbesar. Tulisan ini menjelaskan seberapa besar kontribusi ikan cucut (Requiem shark sp.) sebagai hasil tangkapan dalam perikanan pancing rawai permukaan, dengan studi kasus dari 3 lokasi pendaratan ikan penting di Indonesia.

\section{BAHAN DAN METODE}

Data komposisi jenis hasil tangkapan ikan cucut (Requiem shark sp.) dari perikanan artisanal diperoleh dari pendaratan Palabuhan Ratu (Jawa Barat) dan Cilacap (Jawa Tengah) yang merupakan basis pendaratan ikan dari kapal pancing rawai tuna. Pengambilan data dilakukan pada bulan Maret, Juni, Agustus, dan Oktober 2004.

Identifikasi jenis dilakukan dengan menggunakan kunci identifikasi oleh Compagno (1984); Last \& Stevens (1994); Sainsbury et al. (1985); Gloerfelt-Tarp \& Kailola (1984). Komposisi dan fluktuasi hasil tangkapan ikan cucut (Requiem shark sp.) dengan menggunakan pancing rawai permukaan disajikan berdasarkan pada data kapal yang beroperasi di Samudera Hindia 85 unit yang berasal dari 2 tempat pendaratan ikan utama.

\section{HASIL DAN BAHASAN}

\section{Deskripsi Pancing Rawai}

Dari hasil pengamatan di lapangan pancing rawai dibedakan menjadi 2 yaitu rawai permukaan dan pacing rawai dasar, tetapi dalam tulisan ini hanya akan dikatakan deskripsi dan teknik operasional dari rawai tuna permukaan. Pada umumnya pancing rawai tuna permukaan digunakan oleh nelayan yang beroperasi di perairan Samudera Hindia dan mendaratkan hasil tangkapan di Pelabuhan Ratu dan Cilacap. Jenis alat tangkap ini digunakan untuk menangkap jenis ikan cucut (Requiem shark sp.) yang berada di permukaan (pelagic shark). Diameter tali pancing, nomor tali pancing yang digunakan dan ukuran mata pancing di 2 daerah tersebut relatif sama. Jumlah mata pancing antara 1.200 sampai dengan 1.500 buah, lama operasi penangkapan di laut mencapai 3 minggu. Lama operasi penangkapan ditentukan oleh daerah penangkapan, semakin jauh daerah penangkapan yang dituju akan membutuhkan waktu yang lebih lama. Selain itu, lama operasi 
penangkapan di laut ditentukan juga oleh tonase kapal dan daya jelajah.

Umpan yang digunakan untuk menangkap ikan cucut adalah potongan daging ikan tuna (Scombridae), marlin (Maakaira indica), dan pedang (Istiophorus platypterus) dengan bobot potongan kira-kira $200 \mathrm{~g}$, atau dapat juga menggunakan umpan beku jenis ikan layang (Decapterus sp), cumi-cumi (Loligo sp) dengan ukuran panjang antara 15 sampai dengan $20 \mathrm{~cm}$ atau umpan ikan bandeng hidup (Chanos chanos) berukuran kira-kira $100 \mathrm{~g}$ (10 sampai dengan $15 \mathrm{~cm}$ ). Penggunaan umpan hidup segar lebih efektif dibanding umpan beku (FAO, 2000). Oleh karena itu, penggunaan umpan hidup segar sudah umum dilakukan oleh nelayan yang mengoperasikan rawai tuna yang berbasis di Pelabuhan Perikanan Samudera Muara Baru. Umpan segar yang digunakan adalah jenis ikan bandeng (Channos channos) berukuran antara 100 sampai dengan $150 \mathrm{~g}$. Hal ini, diduga ada pergerakkan umpan hidup, selain itu warna sisik yang mengkilap dari ikan umpan dapat menarik perhatian pemangsa atau predator. Menurut Mojetta (1997) dalam menangkap mangsa ikan cucut (Requiem shark sp.) akan mempercepat berenang untuk menangkap mangsa yang berenang lambat atau sedang dalam keadaan istirahat atau berdiam di tempat, kemudian sebagian atau seluruh bagian tubuh mangsa akan ditelan melalui rahang, apabila mangsa berukuran lebih besar dari mulut, maka mangsa akan dipotong dengan menggunakan gigi. Hasil tangkapan ikan cucut (Requiem shark sp.) seperti Carcharhinus falciformis (cucut kejen), Prionace glauca (cucut karet), Carcharhinus brevipinna (cucut lanjaman atau cucut eho), dan Sphyrna lewini (cucut martil atau cucut bengkok) merupakan jenis ikan cucut (Requiem shark sp.) dominan yang tertangkap dengan pancing rawai permukaan di Tanjung Luar (Anung \& Widodo, 2002). Ikan cucut (Requiem shark sp.) tersebut tertangkap pada kedalaman perairan antara 70 sampai dengan $100 \mathrm{~m}$ dari permukaan laut. Hasil penelitian Matsunaga \& Nakano (1999) menunjukkan bahwa Carcharhinus falciformis (silky shark) banyak tertangkap pada kedalaman antara 100 sampai dengan $150 \mathrm{~m}$ pada perairan oseanik di Samudera Pasifik, sedangkan Alopias superciliosus (big eye thresher) lebih banyak tertangkap pada perairan dalam daripada perairan dangkal, hal ini diduga berkaitan dengan kelimpahan ikan-ikan pelagis sebagai mangsa.

\section{Operasi Penangkapan}

Pengoperasian rawai tuna permukaan dilakukan pada posisi di mana pada pancing pertama dan pancing terakhir dipasang tidak searah, tetapi pada setiap 9 buah keranjang (1 keranjang terdiri atas 50 mata pancing) posisi kapal dibelokkan ke arah kanan menuju ke-9 buah keranjang lain sehingga akan membentuk seperti hurup U. Dari pancing terakhir, selanjutnya kapal menuju pancing pertama untuk melakukan penarikan pancing (haulling). Pengoperasian rawai tuna permukaan dapat dilakukan setiap saat sehingga tidak tergantung waktu, dapat dilakukan pada siang maupun malam hari, kecuali pada saat cuaca di laut kurang memungkinkan misal ombak besar, angin kencang dan hujan deras. Lama penurunan pancing atau setting antara 6 sampai dengan 7 jam, tergantung jumlah pancing yang dioperasikan. Penarikan (haulling) dimulai dari pancing yang diturunkan pertama kali dengan lama penarikan antara 11 sampai dengan 14 jam, hal ini tergantung juga pada jumlah pancing yang dioperasikan dan cuaca di laut. Penarikan pancing dilakukan dengan menggunakan alat bantu (line hauller), waktu penarikan berlangsung selama kurang lebih 12 jam.

\section{Komposisi Hasil Tangkapan}

Komposisi hasil tangkapan ikan cucut (Requiem shark sp.) dari rawai tuna permukaan (tuna surface long line) secara bulanan disajikan pada Tabel 1. Hasil tangkapan ikan cucut (Requiem shark sp.) dari bulan Pebruari sampai dengan Desember memperlihatkan komposisi yang bervariasi. Jenis ikan cucut karet atau selendang (Prionace glauca) selalu mendominasi hasil tangkapan setiap bulan yaitu mencapai 40 sampai dengan $90 \%$. Demikian pula, dengan jumlah jenis ikan cucut (Requiem shark sp.) yang tertangkap menunjukkan perbedaan jumlah berdasarkan pada waktu. Hal ini, diduga karena kondisi perairan dan daerah penangkapan yang berkaitan dengan kelimpahan ikan cucut (Requiem shark sp.) berbeda. Dominansi ikan cucut karet atau selendang (Prionace glauca) pada perikanan tuna long line juga telah terjadi di perairan lain misal di Samudera Pasifik, persentase hasil tangkapan spesies ini mencapai 60 sampai dengan $70 \%$ dari hasil total ikan cucut (Requiem shark sp.) yang tertangkap dari tahun 1992 sampai dengan 1995 (Matsunaga \& Nakano, 1999). Sedangkan Francis et al. (2001) mengatakan bahwa hasil tangkapan ikan cucut karet atau selendang (Prionace glauca) mencapai $47,3 \%$ dari tangkapan total rawai tuna atau $94,2 \%$ dari total tangkapan ikan cucut (Requiem shark sp.) dan pari (Elasmobranchii) yang tertangkap di Samudera Pasifik sejak tahun 1988 sampai dengan 1998. Bahkan di Laut Atlantik ikan cucut karet atau selendang (Prionace glauca) yang tertangkap lebih dari $97 \%$ dari total tangkapan ikan cucut (Requiem shark sp.) pelagis selama tahun 1977 sampai dengan 1994 (Simpfendorfer et al., 2002). 
Ikan cucut karet atau selendang (Prionace glauca) termasuk ikan cucut (Requiem shark sp.) oseanik dan epipelagis yang terdapat di perairan dalam sekitar $350 \mathrm{~m}$ dan mampu bermigrasi dengan jarak yang jauh. Dalam perairan jenis ikan cucut (Requiem shark sp.) ini ditemukan sering bergerombol dalam kelompok ukuran dan jenis kelamin (en.wikipedia.org/wiki/ Blue_shark). Jumlah anak yang dilahirkan antara 4 sampai dengan 135 ekor atau yang sering ditemukan di lapangan antara 15 sampai dengan 30 ekor dalam 1 tahun lebih banyak dibandingkan dengan spesies lain dalam famili Carcharhinidae, misal Carcharhinus flaciformis (cucut lanjaman) antara 1 sampai dengan 16 anak atau Carcharhinus sorrah (cucut lanyam) hanya 6 sampai dengan 8 anak yang dilahirkan. Di samping itu, Prionace glauca merupakan spesies ikan cucut (Requiem shark sp.) yang paling luas penyebarannya (Compagno, 1998), sehingga peluang tertangkap lebih besar dibanding spesies lain (White et al., 2006). Oleh karena itu, ikan cucut karet atau selendang (Prionace glauca) selalu mendominasi dalam komposisi hasil tangkapan setiap bulan. Prionace glauca berkembang biak dengan vivaporous dengan kuning telur berupa plasenta (yolk sac placent), dengan masa kandungan 9 sampai dengan 12 bulan. Prionace glauca dapat mencapai umur 5 sampai dengan 6 tahun untuk jenis betina dan 4 sampai dengan 5 tahun untuk jenis jantan. Dalam daftar Merah IUCN, status konservasi hampir terancam (near treatened) (White et al., 2006). Dengan demikian maka, hasil tangkapan dari spesies ini sudah mendapat perhatian yang serius bagi para pemerhati konservasi spesies tertentu. Pada umumnya kelompok ikan cucut (Requiem shark sp.) pelagis termasuk ikan cucut karet atau selendang (Prionace glauca) tidak hanya sering tertangkap dengan rawai tuna permukaan tetapi juga dengan jaring tuna permukaan. Sebagai gambaran hasil tangkapan sampingan ikan cucut (Requiem shark sp.) dari Samudera Hindia dengan menggunakan rawai tuna permukaan dalam 1 tahun $32.927 \mathrm{~kg}$, sedangkan penangkapan dengan menggunakan jaring tuna permukaan $166.032 \mathrm{~kg}$ (Pelabuhan Perikanan Nusantara Cilacap, 2002) atau dengan perbandingan hasil tangkapan ikan cucut (Requiem shark sp.) antara rawai tuna permukaan dengan jaring tuna permukaan 1:5. Secara teknis, Gilman (2007) mengatakan bahwa ada beberapa faktor yang mempengaruhi laju tangkap ikan cucut (Requiem shark sp.) yang tertangkap dengan rawai permukaan yaitu jumlah mata pancing dalam basket atau keranjang, panjang tali pelampung, dan tali cabang yang berhubungan dengan kedalaman posisi umpan dalam pancing ketika berada dalam air. Laju tangkap ikan cucut (Requiem shark sp.) pada rawai tuna juga dapat dipengaruhi oleh jenis umpan yang digunakan.

Tabel 1. Komposisi hasil tangkapan ikan cucut (Requiem shark sp.) pada rawai tuna permukaan Table 1. Sharks catch composition of surface tuna long line

\begin{tabular}{|c|c|c|c|c|c|c|c|c|c|c|}
\hline Month & $\begin{array}{l}\text { Prionace } \\
\text { glauca }\end{array}$ & $\begin{array}{l}\text { Carcharhinus } \\
\text { falciformis }\end{array}$ & $\begin{array}{c}\text { Carcharhinus } \\
\text { sorrah }\end{array}$ & $\begin{array}{c}\text { Alopias } \\
\text { superciliosus }\end{array}$ & $\begin{array}{c}\text { Alopias } \\
\text { pelagicus }\end{array}$ & $\begin{array}{l}\text { Isurus } \\
\text { sp. }\end{array}$ & $\begin{array}{l}\text { Sphyrna } \\
\text { sp. }\end{array}$ & $\begin{array}{c}\text { Carcharhinus } \\
\text { longimanus }\end{array}$ & $\begin{array}{c}\text { Total } \\
\text { (\%) }\end{array}$ & $\begin{array}{c}\text { Unit } \\
\text { of } \\
\text { boat }\end{array}$ \\
\hline$F$ & 67 & & & & 33 & & & & 100 & 5 \\
\hline$M$ & 24 & 20 & 5 & 20 & 20 & 11 & & & 100 & 17 \\
\hline$A$ & 79 & 4 & 2 & & 11 & 4 & & & 100 & 7 \\
\hline$M$ & 89 & 3 & & 2 & 3 & 3 & & & 100 & 14 \\
\hline $\mathrm{J}$ & 87 & 2 & & & 11 & & & & 100 & 11 \\
\hline $\mathrm{J}$ & 84 & & 5 & 2 & 7 & 1 & 1 & 0 & 100 & 13 \\
\hline$A$ & 69 & & & 16 & 14 & & 1 & & 100 & 6 \\
\hline$S$ & 90 & 3 & & 4 & & 3 & & & 100 & 3 \\
\hline 0 & 41 & & 37 & & 22 & & & & 100 & 2 \\
\hline $\mathrm{N}$ & 60 & 1 & 12 & 22 & 5 & & & & 100 & 4 \\
\hline D & 89 & 1 & 5 & 5 & & & & & 100 & 3 \\
\hline Total & 779 & 34 & 66 & 71 & 126 & 22 & 2 & 0 & & 85 \\
\hline
\end{tabular}

\section{Fluktuasi Hasil Tangkapan}

Fluktuasi bulanan hasil tangkapan ikan cucut (Requiem sharksp.) yang dominan tertangkap dengan menggunakan rawai tuna permukaan di Samudera Hindia disajikan pada Gambar 2. Terdapat 4 spesies ikan cucut (Requiem shark sp.) dominan yaitu ikan cucut karet atau selendang (Prionace glauca), cucut monyet (Alopias pelagicus), cucut lanjaman (Carcharhinus sorrah), dan cucut pahitan (Alopias superciliosus). Dari Gambar tersebut nampak bahwa secara umum ke-4 spesies tersebut menunjukkan trend fluktuasi hasil tangkapan sama yaitu menurun dari bulan Pebruari dan meningkat mencapai puncak pada bulan Juli sampai dengan Agustus kemudian hasil tangkapan menurun kembali pada bulan berikut. Meningkat hasil tangkapan ikan cucut (Requiem shark sp.) pada bulan Juli sampai dengan Agustus seiring dengan meningkat persentase ikan cucut (Requiem shark sp.) terhadap hasil tangkapan total rawai tuna permukaan. Persentase hasil tangkapan ikan cucut (Requiem shark sp.) tertinggi 25\% (Gambar 3) terjadi 
pada bulan yang sama, namun berfluktuatif pada bulan Pebruari sampai dengan Juni dan bulan Agustus sampai dengan Desember. Fluktuasi hasil tangkapan ikan cucut (Requiem shark sp.) tersebut diduga berkaitan dengan kondisi cuaca pada saat melakukan penangkapan ikan di laut. Bulan Juli sampai dengan Agustus merupakan periode peralihan musim penghujan ke musim kemarau, pada periode tersebut kondisi di laut dalam keadaan tenang, ombak relatif kecil, dan hembusan angin berkurang sehingga memudahkan nelayan untuk melakukan penangkapan ikan. Wyrtki, (1958) mengatakan bahwa perkembangan puncak tekanan udara tinggi di atas
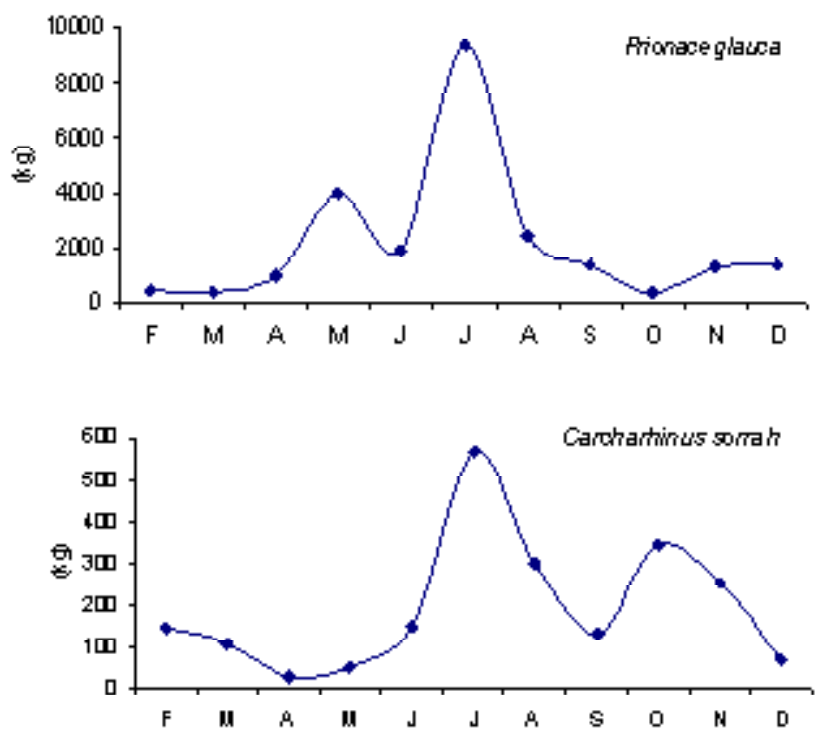

Asia dan lembah tekanan udara rendah di atas Australia dalam bulan-bulan Desember, Januari, dan Pebruari menyebabkan angin yang berhembus di Indonesia angin barat, yang ditandai dengan angin kencang dan hujan lebat. Sebaliknya, dalam bulan Juni sampai dengan Agustus, ada lembah tekanan udara rendah di atas Asia dan puncak tekanan udara tinggi di atas Australia menyebabkan angin yang bertiup di Indonesia pada angin timur, yang ditandai dengan tiupan angin lemah. Sistem tekanan tetap sehingga keadaan ini menyebabkan angin munson bertiup dengan stabil di permukaan laut.
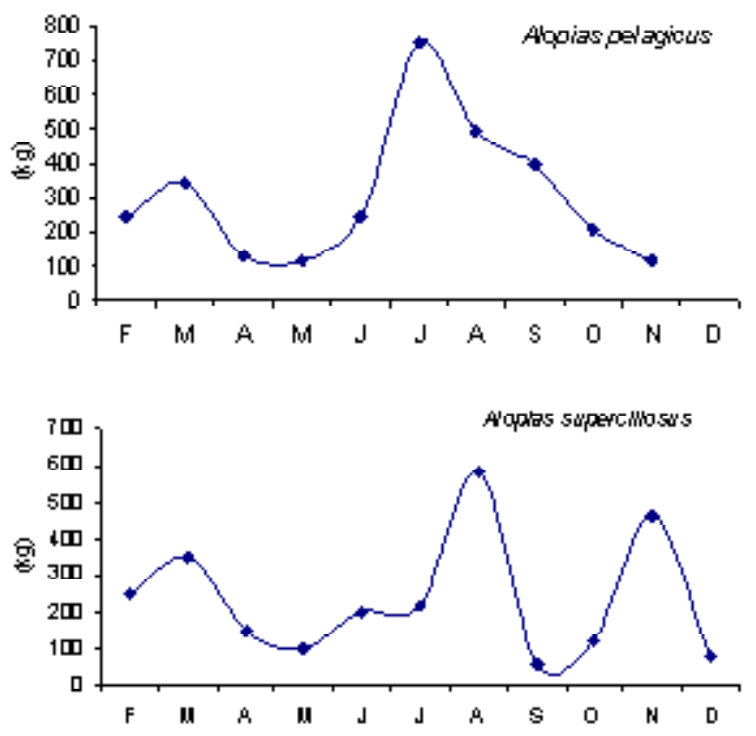

Gambar 2. $\quad$ Fluktuasi hasil tangkapan ikan cucut (Requiem shark sp.) dari rawai tuna permukaan. Figure 2. Sharks (Requiem shark sp.) catch fluctuation of surface tuna long line.

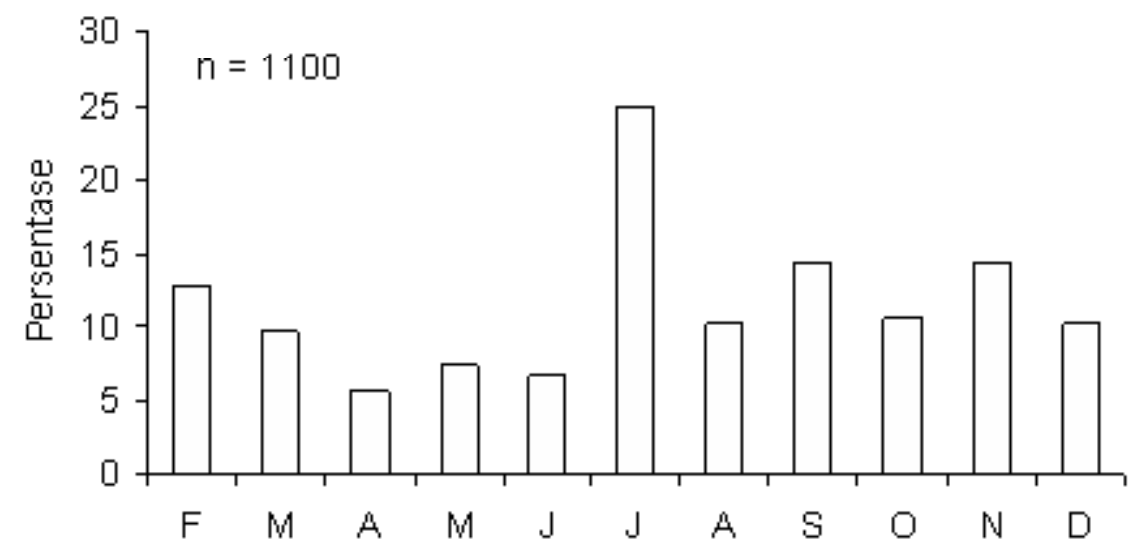

Gambar 3. Persentase ikan cucut (Requiem shark sp.) terhadap hasil tangkapan total tangkapan pada rawai tuna permukaan.

Figure 3. Percentage of shark (Requiem shark sp.) againts total catch of surface tuna long line. 
Berdasarkan pada Gambar 3 dapat dikatakan bahwa persentase hasil tangkapan ikan cucut (Requiem shark sp.) terhadap hasil tangkapan total dari alat tangkap rawai tuna permukaan yang beroperasi di perairan Samudera Hindia selama tahun 2004 antara 5 sampai dengan 25\%. Persentase ini cukup memberikan kontribusi nyata terhadap hasil tangkapan total pada perikanan rawai tuna permukaan. Pada umumnya nelayan rawai tuna menyadari bahwa ikan cucut (Requiem shark sp.) memiliki nilai ekonomis tinggi terutama sirip, sehingga dapat dikatakan bahwa meskipun sampai dengan saat ini hasil tangkapan ikan cucut (Requiem shark sp.) dari rawai tuna dianggap sebagai tangkapan sampingan tetapi bagi nelayan dapat menjadi tambahan pendapatan yang cukup berarti.

\section{Daerah Penangkapan}

Aktivitas penangkapan rawai tuna permukaan yang dilakukan oleh nelayan yang berasal dari Pelabuhan Ratu dan Cilacap adalah di perairan Samudera Hindia pada posisi geografi antara $5^{\circ}-20^{\circ}$ LS dan antara $106^{\circ}-119^{\circ} \mathrm{BT}$. Berdasarkan pada data posisi geografi, maka daerah penangkapan dapat disajikan pada Gambar 4.

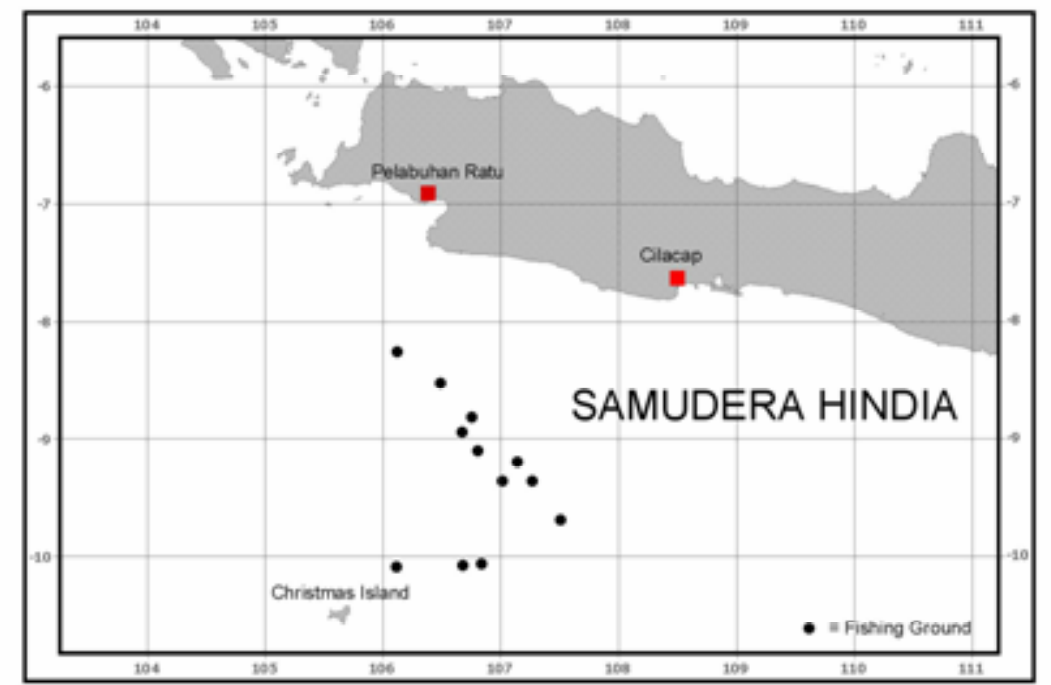

Gambar 4. Daerah penangkapan rawai tuna permukaan tahun 2004. Figure 4. Fishing area of tuna long lines (2004).

\section{KESIMPULAN}

Komposisi hasil tangkapan ikan cucut (Requiem shark sp.) secara bulanan pada rawai tuna permukaan terdiri atas 6 spesies. Jenis ikan cucut karet atau selendang (Prionace glauca) selalu mendominasi hasil tangkapan total ikan cucut (Requiem sharksp.) setiap bulan yaitu antara 40 sampai dengan $90 \%$. Sedangkan jenis ikan cucut (Requiem shark sp.) lain seperti Carcharhinus falciformis, Carcharhinus sorrah, Alopias superciliosus, Alopias pelagicus, dan Isurus sp. antara 3 sampai dengan $30 \%$. Hasil tangkapan ikan cucut (Requiem shark sp.) berfluktuatif berdasarkan pada jenis dan waktu. Hasil tangkapan ikan cucut (Requiem shark sp.) tertinggi terjadi pada bulan Juli sampai dengan Agustus, hal ini berkaitan dengan kondisi kelimpahan ikan cucut (Requiem sharksp.), teknik penangkapan, daerah penangkapan dan kondisi cuaca pada saat melakukan penangkapan di laut.

\section{PERSANTUNAN}

Kegiatan hasil riset dari dana pribadi. Penulis mengucapkan terima kasih pada Bapak Ir. Joko Riyanto staf karyawan Pelabuhan Perikanan Samudera Cilacap, dan beberapa staf pegawai Pelabuhan Perikanan Pelabuhan Ratu yang telah membantu dalam memberikan informasi tentang perikanan ikan cucut (Requiem sharksp.).

\section{DAFTAR PUSTAKA}

Anung, A. \& J. Widodo. 2002. Perikanan cucut artisanal di perairan Samudera Hindia Selatan Jawa dan Lombok. Jurnal Penelitian Perikanan Indonesia Edisi Sumber Daya dan Penangkapan. Vol.8 No.1. Hal.75-83. 
Bonfil, R. 2002. Trend and patterns in world and Asian elasmobranch fisheries. In S. L. Fowler, T. M. Reed \& F. A. Dipper (Eds.). Elasmobrach biodiversity conservation and management: Proceeding of the International Seminar and Workshop in Sabah. July 1997 (pp. 15-24). Gland, Switzerland, and Cambridge, U. K. IUCN-The World Conservation Union.

Castro, J. I., C. M. Woodley, \& R. L. Brudek. 1999. A Preliminary evolution of the status of shark. National Oceanographic and Atmospheric Administration. National Marine Fisheries Service Southeast Fisheries Science Center Miami. Florida. USA. FAO. Fisheries Technical Paper No.380.

Compagno, L. J. V. 1984. FAO jenis catalogue. Vol.4. Sharks of the world. An annotated and illustrated catalogue of sharks jenis known to date. Part 1. Hexanchiformes to Lamniformes. FAO Fish. Synop. (125). Vol.4. Pt 1. 249 p.

Compagno, L. J. V. 1998. Sharks. pp. 1193-1366. In K. E. Carpenter \& V. H. Niem (eds). FAO identification guide for fishery purposes. The Living Marine Resources of the Western Central Pacific. Vol.2. Cephalopods, Crustaceans, Holuthurians, and sharks. FAO. Rome.

en.wikipedia.org/wiki/Blue_shark.

FAO. 2000. FAO Marine resources service. Fisheries Management 1. Conservation and Management of Shark. FAO Technical Guidelines for Responsible Fisheries. No.4. Suppl. 1. FAO Rome 37 p.

Francis, M. P., L. H. Griggs, \& S. J. Baird. 2001. Pelagic shark bycatch in the New Zealand tuna long line fishery. Marine Freshwater Research. 2001. 52. 165-178.

Gilman, E. 2007. Shark depredation and unwanted bycatch in pelagic longline fisheries. UNEP Regional Seas. Blue Ocean Institute. New Elangland Aquarium. Project Global. 203 p.

Gloerfelt-Tarp, G. T. \& P. J. Kailola. 1984. Trawled fishes of southern Indonesia and Northwestern Australia. ADAB-DFG-GTZ. Singapore. 406 p.
IUCN. 2005. The IUCN red list of threatened speciessummary statistics. Retrieved 9 May 2005, from http://www.redlist.org/info/tables/table3a.html

Last, P. R. \& J. D. Stevens. 1994. Sharks and rays of Australia. Fisheries Research and Development Corporation. $513 p$.

Matsunaga, H. \& H. Nakano. 1999. Species composition and catch per unit of effort of pelagic sharks caught by Japanese long line research and training vessels in the Pacific Ocean. Fisheries Science. 65 (1). 16-22 (1999).

Mojetta, A. 1997. Sharks, history, and biology of the lords of the sea. White Star Publishers. Milan. 168 p.

Pelabuhan Perikanan Nusantara Cilacap. 2002. Laporan Hasil Tangkapan Ikan di Perairan Samudera Hindia. Intern report.

Sainsbury, K. J., Kailola, P. J., \& Layland, J. J. 1985. Continental shelf fishes of northern and northwestern Australia-an illustrated guide. CSIRO Division of Fisheries Research. Clouston \& Hall and Peter Pownall Fisheries Information Service. Canberra. $375 \mathrm{p}$.

Simpfendorfer, C. A., R. E. Hoeter, \& U. Bergman. 2002. Results of a fishery independent survey for pelagic sharks in the western North Atlantic. 19771994. Fisheries research. 55. (2002). 175-192.

Stevens, J. D., R. Bonfil, N. K. Dulvy, \& P. A. Walker. 2000. The effect of fishing on sharks, rays, and chimaeras (chondrichthyans), and the implications for marine ecosystem. ICES Journal of Marine Science. 57. 476-494.

Wyrtki. 1958. The water exchange between the Pacific and the Indian Ocean in relation to upwelling process. Proccidding Nith Pacific Science Congress. 16. 61-66.

White, W. T., P. R. Last, J. D. Stevens, G. K. Yearsley, Fahmi, \& Dharmadi. 2006. Economically important sharks and rays of Indonesia. Canberra. ACIAR. $329 \mathrm{p}$. 